University for Business and Technology in Kosovo

UBT Knowledge Center

UBT International Conference

2016 UBT International Conference

Oct 28th, 9:00 AM - Oct 30th, 5:00 PM

\title{
Extraction of Valuable Metals from Trepca Landfilled Lead Smelting Slags with WELC Process
}

\author{
Afrim Osmani \\ University for Business and Technology, afrim.osmani@ubt-uni.net \\ Musa Rizaj \\ University of Isa Boletini
}

Follow this and additional works at: https://knowledgecenter.ubt-uni.net/conference

Part of the Engineering Commons, and the Physical Sciences and Mathematics Commons

\section{Recommended Citation}

Osmani, Afrim and Rizaj, Musa, "Extraction of Valuable Metals from Trepca Landfilled Lead Smelting Slags with WELC Process" (2016). UBT International Conference. 45. https://knowledgecenter.ubt-uni.net/conference/2016/all-events/45

This Event is brought to you for free and open access by the Publication and Journals at UBT Knowledge Center. It has been accepted for inclusion in UBT International Conference by an authorized administrator of UBT Knowledge Center. For more information, please contact knowledge.center@ubt-uni.net. 
Book of Proceedings

International Conference on Mechatronics, Sciences in Energy Efficiency Engineering,

System Engineering and Robotics

\title{
EXTRACTION OF VALUABLE METALS FROM TREPCA LANDFILLED LEAD SMELTING SLAGS WITH WELC PROCESS
}

\author{
Afrim Osmani ${ }^{1}$, Musa Rizaj ${ }^{2}$, \\ ${ }^{1}$ UBT - Higher Education Institution, Lagjja Kalabria, 10000 p.n., \\ Prishtine, Kosovo \\ ${ }^{2}$ University of "Isa Boletini", FGJSH, Dep. Metallurgy and Materials, \\ Mitrovica, Kosovo
}

\begin{abstract}
The landfilled slags obtained over the years from reduction smelting of lead agglomerates at the Trepca lead smelter contain numerous components as metal oxides and sulphides as well as metals in elementary state. Among others they contain various forms of $\mathrm{Pb}, \mathrm{Zn}, \mathrm{Cu}, \mathrm{Ag}, \mathrm{Ge}, \mathrm{Tl}, \mathrm{In}, \mathrm{As}, \mathrm{Bi}, \mathrm{Sb}$. These are valuable elements that may turn these slags to a new important "raw material" for their extraction.

Based on the chemical composition results of 354 samples and mineralogical analysis then the quantity of these landfilled slag, which is estimated to be about 3 million tons it was concluded that these slags constitute a feasible waste for extraction of valuable metals.

In order to select the optimal process for the separation/extraction of these metals some existing extraction processes were studied based on fuming, electro thermic separation etc. Waelz process was also analysed since it enables the processing of solid slag whose components have different vapour pressures, assures low rate of metal loss during processing and achieves generally good results in terms of economic feasibility.
\end{abstract}

\section{Introduction}

In metallurgy of lead in Trepca complex, slag obtained from the smelting reduction process in the blast furnace and this chemical content : $\mathrm{ZnO}(8-14 \%), \mathrm{Pb}(0.5-1.8 \%), \mathrm{Cu}(0.15-0.3 \%)$, and $\mathrm{Ag}$ metals precious values $(10 \mathrm{~g} / \mathrm{t})$, and this composition oxides: $\mathrm{CaO}(18-20 \%), \mathrm{FeO}$ (30-38\% SiO2 (20-24\%), $\mathrm{MgO}$ (2-4), and $\mathrm{Al} 2 \mathrm{O} 3$ (4-7\%).

The ratio between the slag components is dependent on the amount of $\mathrm{ZnO}$ in the slag, so by increasing the amount of $\mathrm{ZnO}$ in the slag, increase the amount of $\mathrm{FeO}$, while the reduced amount of $\mathrm{SiO} 2$ and $\mathrm{CaO}$.

At slag from the shaft furnace exceed $80 \% \mathrm{Zn}, 20 \% \mathrm{Cu}$ and $1-1.5$, but in cases of disorder was the smelting reduction process, the amount of lead ranges from 3-5\%. But in the slag it passes an amount of rare metals such as $\mathrm{Ge} 65 \%, 55 \% \mathrm{Tl}, 45 \%$ and $30 \% \mathrm{In}$. 
EXTRACTION OF VALUABLE METALS FROM TREPCA LANDFILLED LEAD SMELTING SLAGS WITH WELC PROCESS

The following table is given granulometric composition of slag shaft furnace that lead in metallurgy.

Tab.1.Granulometric composition of slage by shaft furnace

\begin{tabular}{||l|l|l|l|l|l|l|l|l|l|l|l|l||}
\hline $\mathrm{mm}$ & 0.06 & 0.04 & 0.15 & 0.18 & 0.20 & 0.22 & 0.35 & 0.42 & 0.50 & 0.31 & 0.67 & 1.4 \\
\hline$\%$ & 0.68 & 0.85 & 1.3 & 0.92 & 1.2 & 2.4 & 3.1 & 3.8 & 2.7 & 3.9 & 4.1 & 4.8 \\
\hline
\end{tabular}

\section{Experimental Part Chemical Analysis}

Determination of chemical analysis of slag through the volumetric method is a support for research opportunities for the application of advanced processes, with the aim of exploitation of metal present in the slag.

Analysis of the chemical composition have been conducted on 354 samples and values obtained were expected and reasonable.Chemical analysis of composition are given in tables, as follows.

Tab.2.Chemical analysis of slage by shaft furnace

\begin{tabular}{|l|l|l|l|l|l|l|}
\hline $\mathrm{Pb} \%$ & $\mathrm{ZnO} \%$ & $\mathrm{FeO} \%$ & $\mathrm{CaO} \%$ & $\mathrm{SiO}_{2} \%$ & $\mathrm{~S} \%$ & $\mathrm{Cu} \%$ \\
\hline 2,35 & 10,21 & 39,56 & 18,31 & 19,84 & 0,85 & 0,22 \\
\hline 1,37 & 11,05 & 31,28 & 9,35 & 24,63 & 1,27 & 0,31 \\
\hline 1,62 & 12,15 & 43,12 & 20,23 & 28,51 & 1,15 & 0,36 \\
\hline 0,57 & 9,28 & 38,14 & 18,62 & 24,00 & 0,90 & 0,18 \\
\hline 1,21 & 9,78 & 35,23 & 16,45 & 21,37 & 1,35 & 0,12 \\
\hline 0,98 & 8,68 & 33,36 & 16,27 & 20,18 & 1,31 & 0,19 \\
\hline 1,00 & 10,24 & 37,14 & 20,71 & 21,53 & 2,12 & 0,21 \\
\hline 0,80 & 7,80 & 35,00 & 15,22 & 21,36 & 1,65 & 0,24 \\
\hline 1,18 & 10,14 & 36,52 & 17,35 & 26,75 & 1,23 & 0,14 \\
\hline 3,12 & 11,86 & 40,37 & 18,06 & 27,53 & 1,06 & 0,27 \\
\hline
\end{tabular}


Book of Proceedings

International Conference on Mechatronics, Sciences in Energy Efficiency Engineering,

System Engineering and Robotics

\section{Mineralogical Analysis}

To have a complete overview of material components is done research of mineralogical analyzes of granulated slag from shaft furnaces in Trepca complex, through rengenometric method.

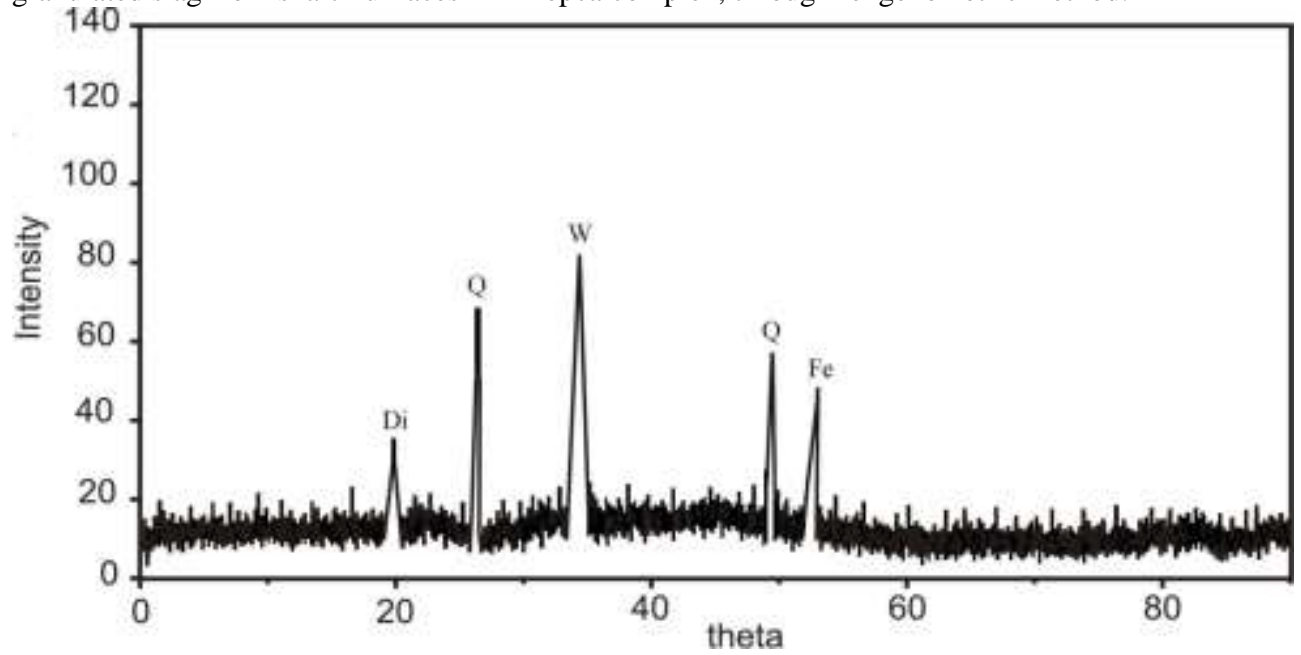

Fig.1.

Where are: Di-Diopsidi $\left(\mathrm{CaMgSiO}_{2} \mathrm{O}_{6}\right)$

Q-Geleniti $\left(\mathrm{Ca}_{2} \mathrm{Al}_{2} \mathrm{SiO}_{7}\right)$

W-Vistit (FeO)

Fe- Elementari Iron $(\mathrm{Fe})$ 
EXTRACTION OF VALUABLE METALS FROM TREPCA LANDFILLED LEAD SMELTING SLAGS WITH WELC PROCESS

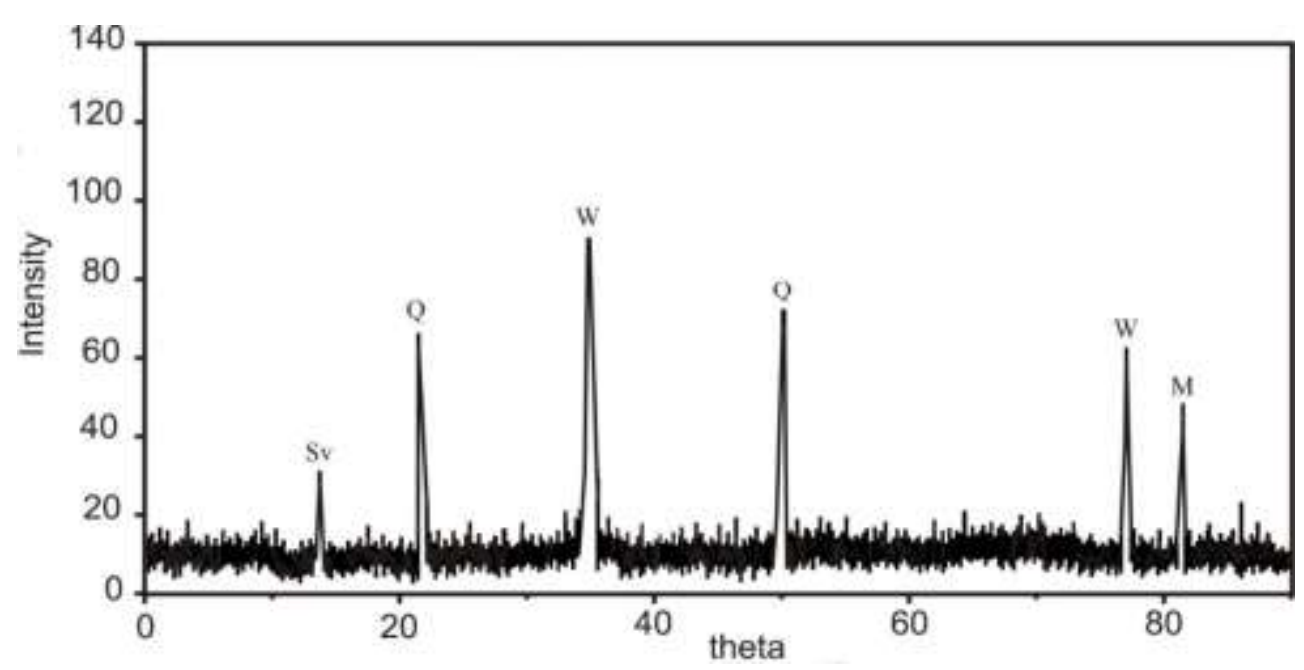

Where are: Sv-Svalerit (ZnS)

Fig.2

Q-Geleniti $\left(\mathrm{Ca}_{2} \mathrm{Al}_{2} \mathrm{SiO}_{7}\right)$

W-Vistit (FeO)

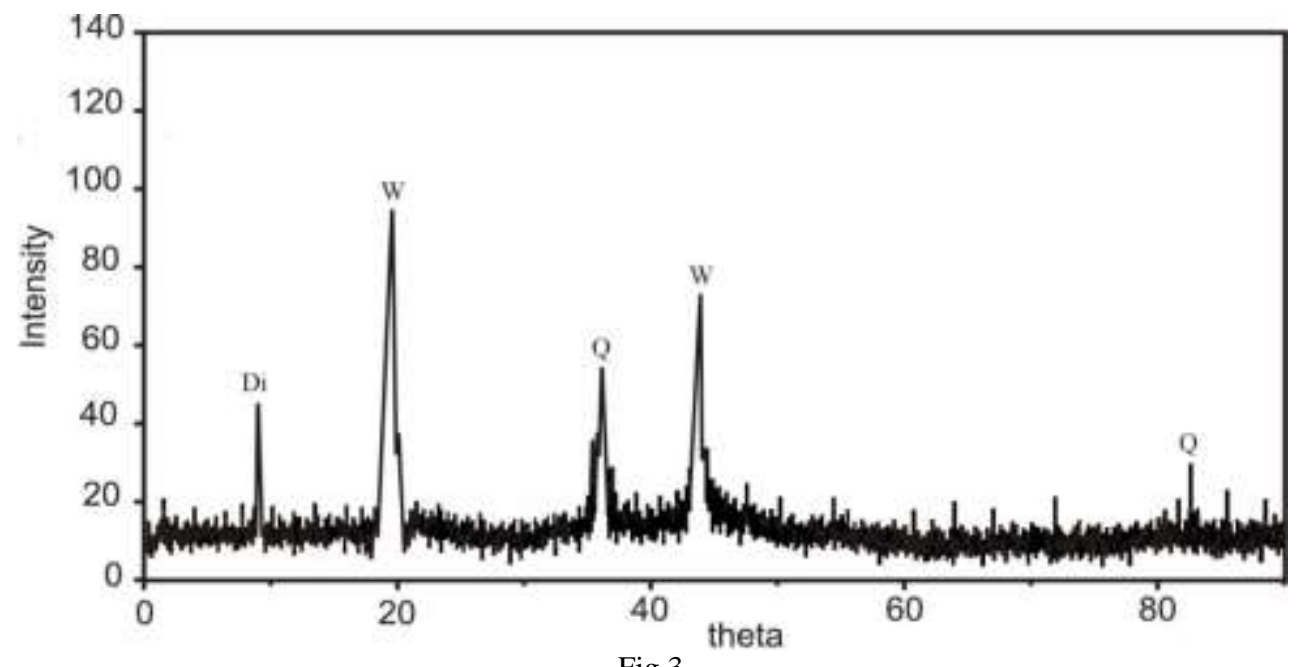

Where are: Di-Diopsidi $\left(\mathrm{CaMgSiO}_{2} \mathrm{O}_{6}\right)$

Fig.3

Q-Geleniti $\left(\mathrm{Ca}_{2} \mathrm{Al}_{2} \mathrm{SiO}_{7}\right)$

W-Vistit (FeO) 
Book of Proceedings

International Conference on Mechatronics, Sciences in Energy Efficiency Engineering,

System Engineering and Robotics

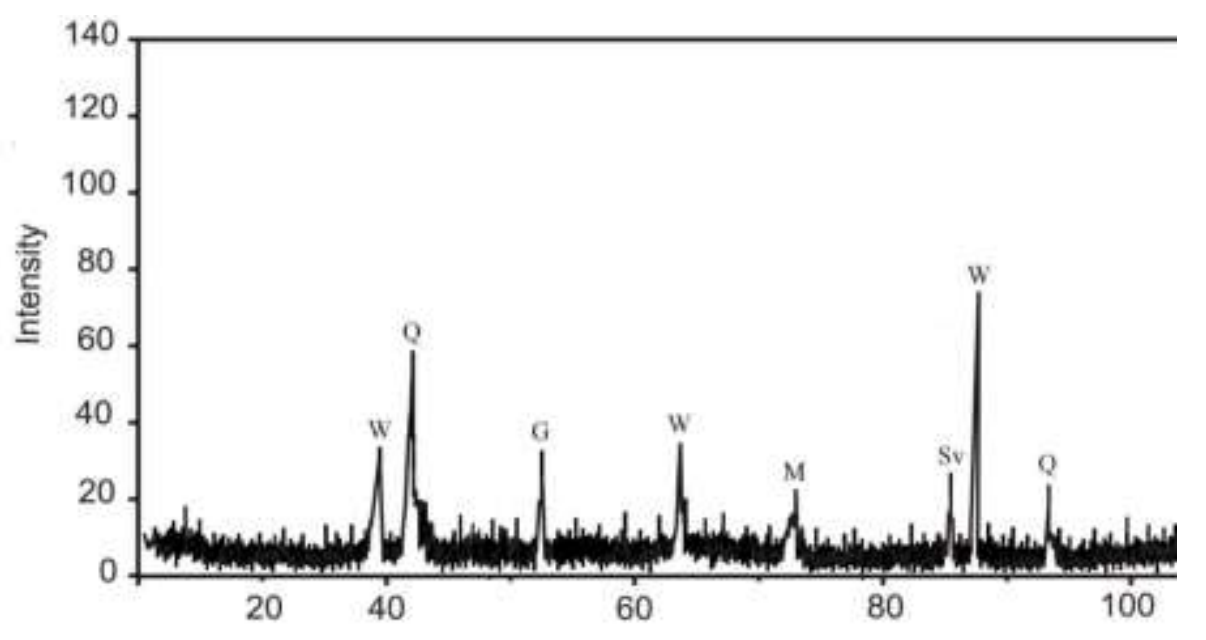

Fig.4.

Where are: M-Magnetit $\left(\mathrm{FeO} \mathrm{Fe}_{2} \mathrm{O}_{3}\right)$

Q-Geleniti $\left(\mathrm{Ca}_{2} \mathrm{Al}_{2} \mathrm{SiO}_{7}\right)$

W-Vistit ( $\mathrm{FeO})$

G-Galeniti (PbS)

\section{Slag Treatment}

Granulated slag treatment shaft furnace that is done through the process of Vellc. The process takes place in oven cylindrical rotation, at an angle of 3-5 ${ }^{\circ}$. Sharzha enters at the furnace through head of the furnace, while in the outgoing furnace slag and inserted Sand blast issued. Entering in the composition of slag and dross of lead and coke, which is used as fuel and as reducentm subject.

After the introduction of slag in the furnace, the furnace starts movement along the horizontal axis and the angle under the influence of furnace sharzha part moving towards its exit, which in this case is done by heating it at a temperature of $1100-1200^{\circ} \mathrm{C}$, the heat freed of coke combustion and heatof exothermic reactions.

When passing through the furnace becomes reduction of oxides of zinc, lead and cadmium, where the metal vapor in the exhaust gases pass process.

The reactions based on the process are:

$$
\begin{aligned}
& \mathrm{C}+\mathrm{O}_{2}=\mathrm{CO}_{2} \\
& \mathrm{CO}_{2}+\mathrm{C}=2 \mathrm{CO} \\
& \mathrm{ZnO}+\mathrm{CO}=\mathrm{Zn}+\mathrm{CO}_{2} \\
& \mathrm{PbO}+\mathrm{CO}=\mathrm{Pb}+\mathrm{CO}_{2}
\end{aligned}
$$

Balanc constant for this reaction is: 
EXTRACTION OF VALUABLE METALS FROM TREPCA LANDFILLED LEAD SMELTING SLAGS WITH WELC PROCESS

$\mathrm{K}=\mathrm{P}_{\mathrm{A}} \cdot[\mathrm{PbO}]_{\mathrm{Sl}} / \mathrm{P}_{\mathrm{B}}$

$\mathrm{P}_{\mathrm{A}} / \mathrm{P}_{\mathrm{B}}=\mathrm{K} /\{\mathrm{PbO}]_{\mathrm{S} I}$

$\mathrm{P}_{\mathrm{A}}, \mathrm{P}_{\mathrm{B}}$ and $[\mathrm{PbO}]_{\mathrm{sl}}$ are partial pressures of $\mathrm{CO}, \mathrm{CO}_{2}$ and $\mathrm{PbO}$. From the above reactions it can be seen that the reduction of $\mathrm{PbO}$, or any other metal oxide from slag, need higher concentration of $\mathrm{CO}$ in the exhaust gases of the process as the lower the concentration of lead oxide in the slag.

And the development reactions:

$\mathrm{ZnO} \mathrm{SiO}_{2}+\mathrm{CO}=\mathrm{Zn}+\mathrm{SiO}_{2}+\mathrm{CO}_{2}$

$\mathrm{ZnO}+\mathrm{CO}=\mathrm{Zn}+\mathrm{CO}_{2}$

$\mathrm{PbO} \mathrm{SiO} 2+\mathrm{CO}=\mathrm{Pb}+\mathrm{SiO}_{2}+\mathrm{CO}_{2}$

$\mathrm{PbO}+\mathrm{CO}=\mathrm{Pb}+\mathrm{CO}_{2}$

The passing rate of the zinc from the slag in the exhaust gases of the process ranges from $90-93 \%$, while that of $\mathrm{Pb}$ ranges from $90-92 \%$, and that of cadmium from 99-99.9\%. The composition of the oxide powder is: $60-65 \% \mathrm{Zn}, 11-15 \% \mathrm{~Pb}, 0.5-1 \% \mathrm{Cd}$, while the composition of the slag (clinker) is: $0.5-0.8 \% \mathrm{Zn}, 0.3-0.5 \% \mathrm{~Pb}, 0.5-0.8 \% \mathrm{Cu}, 15-20 \% \mathrm{C}, 200-300 \mathrm{~g} / \mathrm{t}$ and $0.5-0.8 \mathrm{~g} / \mathrm{tAu}$.

Vapor of these metals gained with the process of reduction, in contact with the oxygen of the air which enter the furnace oxidized at proper (due, necessary) oxides , as follows:

$2 \mathrm{Zn}+\mathrm{O}_{2}=2 \mathrm{ZnO}$

$2 \mathrm{PbO}+\mathrm{O}_{2}=2 \mathrm{PbO}$

Oxides formed in powder form in the gases pass and then issued us process for cleaning the gas system.

These oxides from the system for cleaning the gas transferred to the metallurgy of zinc, which are subject to processing hidrometalurgjik during which process zinc and other elements pass in the digestion of acid sulfurik and after solution cleaning, zinc undergoes the process of electrolysis, while lead concentrate in the remaining solid and transferred to the production of lead metallurgy.

The remainder of the slag at the end of the process Vellc undergoing processing in copper metallurgy unless contains significant amounts of copper on the contrary can be used in building materials industry.

\section{Discussion of results}

From the analysis of the chemical composition clearly seen that the process of smelting slag from shaft furnaces reduction has different chemical composition.

Chemical composition of slag depends of its properties, such as melting temperature, viscosity, specific weight, etc., that has affect at the technical and economical parameters of the process.

Mineralogical analysis on samples from the data shows the presence of components useful and important for Welc process. So we have presence of $\mathrm{PbS}, \mathrm{PbO}$ and $\mathrm{ZnO}$, which are concentrated in the part of the magnetic fraction of the granulated slag.

-Analysis of the chemical composition are in the ranges of slag and shaft furnace that can be subject to processing

by

Welc

process.

-The contents of $\mathrm{Zn}$ is in proportion to the amount of $\mathrm{FeO}, \mathrm{CaO}$ and $\mathrm{SiO}$. 
Book of Proceedings

International Conference on Mechatronics, Sciences in Energy Efficiency Engineering,

System Engineering and Robotics

-Quantity Of $\mathrm{Zn}$ in the slag is suitable for processing with Welc process.

-Quantity Of $\mathrm{Cu}$ is lower, but the $\mathrm{Ag}$ content of 10-15 g/t affects at the profitability of the process.

-So amount of $\mathrm{Pb}$ is justifiable for processing with Welc process, especially when taking into account the profitability of the process of $\mathrm{Pb}$ in Trepca complex by starting process, a process which is followed by loss of lead in the slag.

-So amount of $\mathrm{Pb}$ in slag is high during the disorder was the process used in the blast furnace.

\section{Summary}

In metallurgy of lead in recent decades are the current trends for the modernization of the production process. These tendencies are bound by the impoverishment of mineral rich and as well as the need for the use of lead complex concentrates.

Industry development in recent decades has marked a trend of building high, but such a trend is also faced with the lack of raw materials with high quality and inexpensive.

Therefore Welc application process in Trepca Complex will not only resulted in increased production of lead and other metals present, but we will also influenced at Trepca flexibility in terms of the exploitation of the remaining material from the manufacturing process.

Welc process in this way would be reasonable not only in economic terms but also and environmental.

\section{References:}

1. Bjorn Lindqvist: Technical experiencein the smelting of various lead and cooper raw materials in the Boliden Ronskar plant.

2. V.A. Dolgov. E. V.Jakov, J. Burda, K. Vurm : Cvetnih Metali, Moskva 1990.

3. Branislav G. Nikoliq, Rajko ZH. Vraqar : Ekstraktivna Metalurgija Olova, Beograd 1995.

4. Institute for Lead and Zinc: Mitrovica,1986.

5. Internet

6. A.G.Matyas, P.T.Mackey:Metalurgy of the direct smelting of lead, JOM, Nov.1976. 